SHS Web of Conferences 2, 00037 (2012)

DOI: $10.1051 /$ shsconf $/ 20120200037$

(C) Owned by the authors, published by EDP Sciences, 2012

\title{
Characteristiscs of fatal patient cases out of Riga hospitals
}

\author{
S. Vane ${ }^{1}$, R. Kleina ${ }^{2}$ and A. Smits ${ }^{3}$ \\ ${ }^{1}$ Riga Eastern Clinical University Hospital, Latvia \\ ${ }^{2}$ Baltic International Academy, Latvia \\ ${ }^{3}$ Rĭga Stradinš̌ University, Latvia
}

\begin{abstract}
Health care system becomes less accessible to the people in Latvia. Health insurance is practically destroyed from April, 2010. The aim of our study is to analyze reasons of death of persons who died out of hospital in Riga. We have investigated 130 post mortem examination protocols from Pathology centre of Riga Eastern Clinical university hospital. We have evaluated the information from family doctor and ambulance care medical staff. In our analyzed group 58\% of persons were found dead at home without any medical aid but $25 \%$ - died in the ambulance car after call to public institutions. Alarming is fact that $43,8 \%$ of patients died at $4-5$ th decade of age. There was also such vulnerably group as homeless people. The most common reasons of death were acute and chronic variations of cardio-vascular and lung curable pathologies. In Latvia there is urgent necessity of costless medical offices for poor and defenceless persons. Patient's delay in seeking medical help is the decisive phase for late diagnosis of diseases and mortality. It is necessary to renew health insurance system in Latvia. All levels of medical staff and students of medical universities must be involved in providing information on early disease symptoms, diagnosis and treatment options in different media.
\end{abstract}

Key words: death without medical aid

It is proved that health and social problems are associated with inequality but they are not related to average income levels. Gini-coefficient of inequality: this is the most commonly used measure of inequality. The coefficient varies between 0 , which reflects complete equality and 1 , which indicates complete inequality. Gini index includes data on alcoholism, life expectancy, social mobility, mental illness and other factors. In Latvia, it is the highest in European Union (37,4) in comparison for instance with Hungary - 24,7 (Raudseps, 2011). Accordingly the reports in Bissell 33,9\% of people in Latvia are connected with impoverishment or are socially suppressed/pushed back but $26,5 \%$ of inhabitants live in poverty (web.worldbank.org). After the year 1990 part of population was excluded from economic life, has got depression, alcoholism and indifferent attitude towards life and their health. Health care system becomes less accessible to the people in Latvia. Health insurance system is practically destroyed from April, 2010.

The aim of the study is to analyze reasons of death of persons who died out of hospital without medical aid in Riga.

\section{Material and methods}

We have evaluated 130 post mortem examination protocols from Pathology centre of Riga Eastern Clinical university hospital from persons who died without medical aid. We have evaluated the information from family doctor and ambulance care medical staff. From medical documentation we have taken into consideration: 1) the main diagnose; 2) its complications; and 3) concomitant pathologies of patients. All results were evaluated statistically with MS Excel programmer Data analyses. We have used descriptive statistics of analyzed cases (Arhipova, Bāliņa, 2000; Gringlazs, Kopitovs, 2003).

This is an Open Access article distributed under the terms of the Creative Commons Attribution License 2.0, which permits unrestricted use, distribution, and reproduction in any medium, provided the original work is properly cited. 


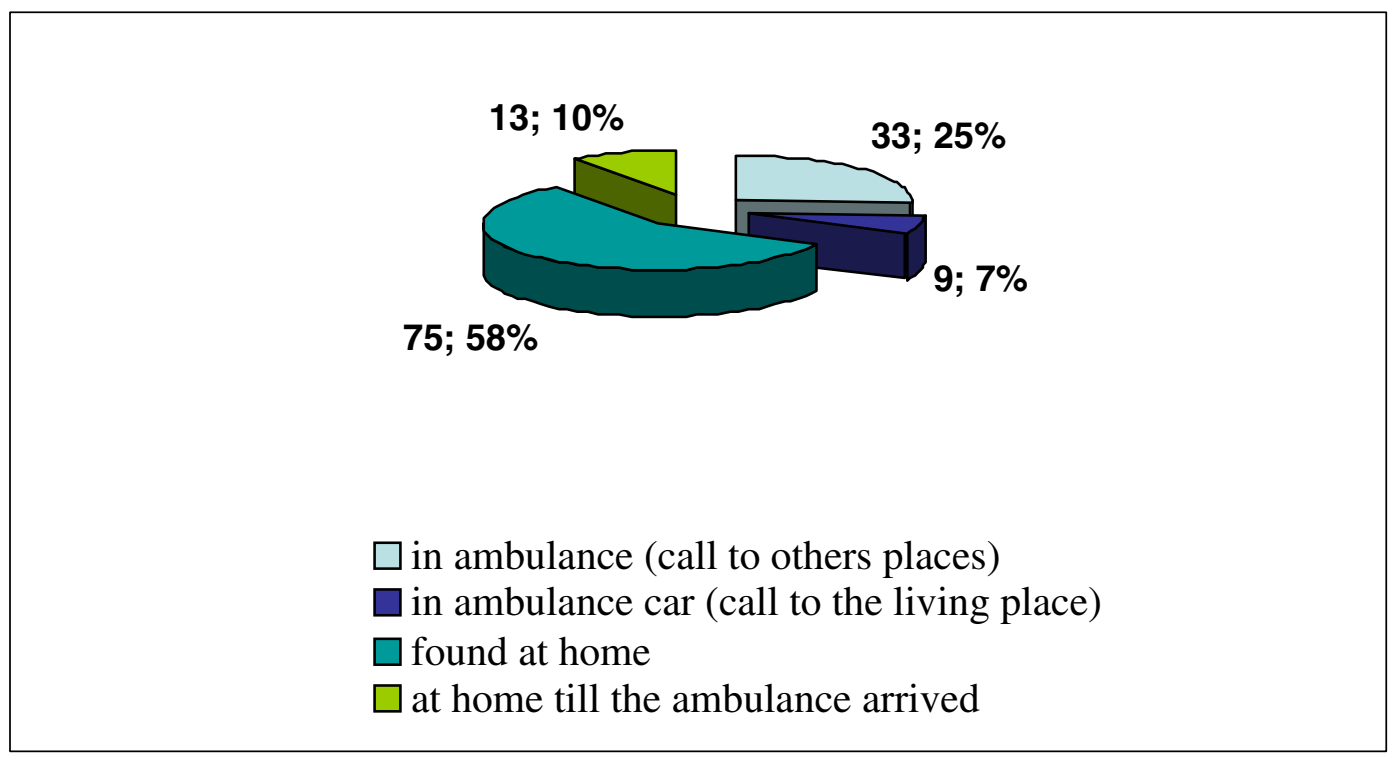

Figure 1. The most common sites of patient death without medical aid.

\section{Results}

We have analyzed 130 cases of dead persons out of hospitals without any health care (Figure 1). 13 patients died at home till the ambulance car arrived but $58 \%$ of persons were found dead at home without any medical aid. In urgent situations part of people usually are calling for ambulance. 9 patients died in ambulance car after call to the living place but 33 persons died in the ambulance car after call to others places (work place, street, public institutions).

In the documentation from family doctors of Riga, the most common information was that the patient has not visited general practitioner or there was request to do autopsy to detect reason of death. The average age of persons who died at home was 56 years but it varied from 26 till 96. Ratio female to male was $1: 1,8.43,8 \%$ of patients $(n=57)$ died before they were retired at able-bodied age mainly at $4^{\text {th }}$ and $5^{\text {th }}$ decade (Figure 2 ). There was also such vulnerably group as homeless people.

The most common diseases of persons who died at home without treatment are showed in Figure 3.

The most common cardio-vascular pathologies were coronary heart disease and cardiomyopathy in $61 \%$ of cases. One fourth of cardiomyopaties were of alcoholic origin as we have found in these patients also liver steatosis and liver cirrhosis (Kleina, 2003, 2006). Between lung diseases were lobar pneumonia and chronic bronchitis with complications. In cases of acute pneumonia there were chronic background pathologies. Therefore in these patients at home without treatment there were developed severe abscess and pleural empyema. Persons before hospitalization died also from some infections like lung tuberculosis, erysipelas and sepsis after peritonitis. In $6 \%$ we have found undiagnosed malignant tumours during patients' life. Most of them in gastrointestinal tract with severe posthemorrhagic anaemia (Latvian population health and health care review, 2009).

All analyzed situations of death at home may be divided into: acute and chronic.

To acute cases belong acute pneumonia (14 cases) and myocardial infarction (28 patients) which needed quick diagnostics and treatment by emergency medicine but patients have not received it till ambulance car arrived. Between the long lasting pathologies in our analyzed group of cases were chronic coronary heart disease, liver cirrhosis, chronic pancreatitis and oncology processes which had symptoms of the disease for many years. Similar facts are shown also in other cities of Latvia (Yearbook of the 
Int. Conf. SOCIETY. HEALTH. WELFARE; Congr. of Rehabilitation Doctors of Latvia

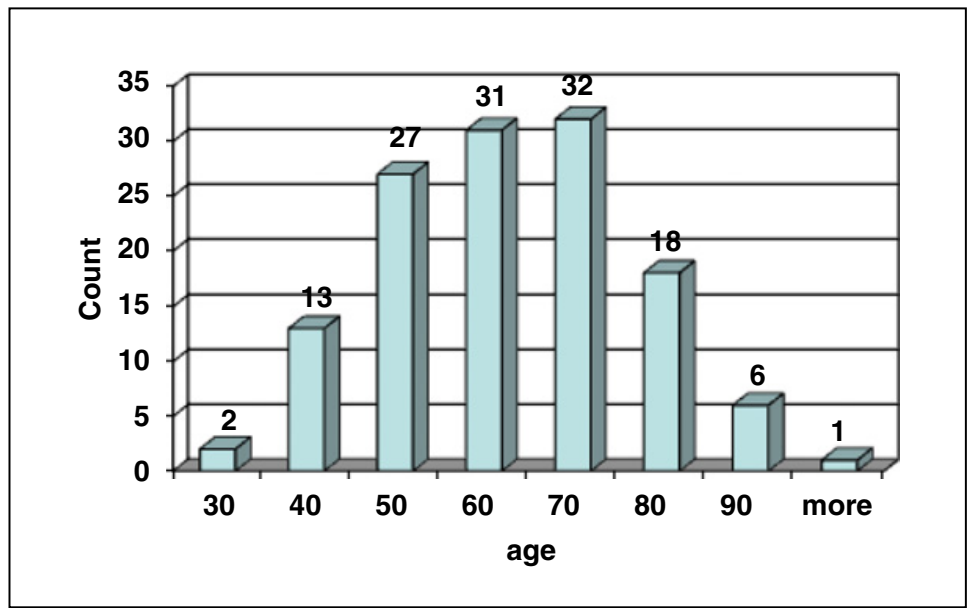

Figure 2. The age of persons who died out of hospitals.

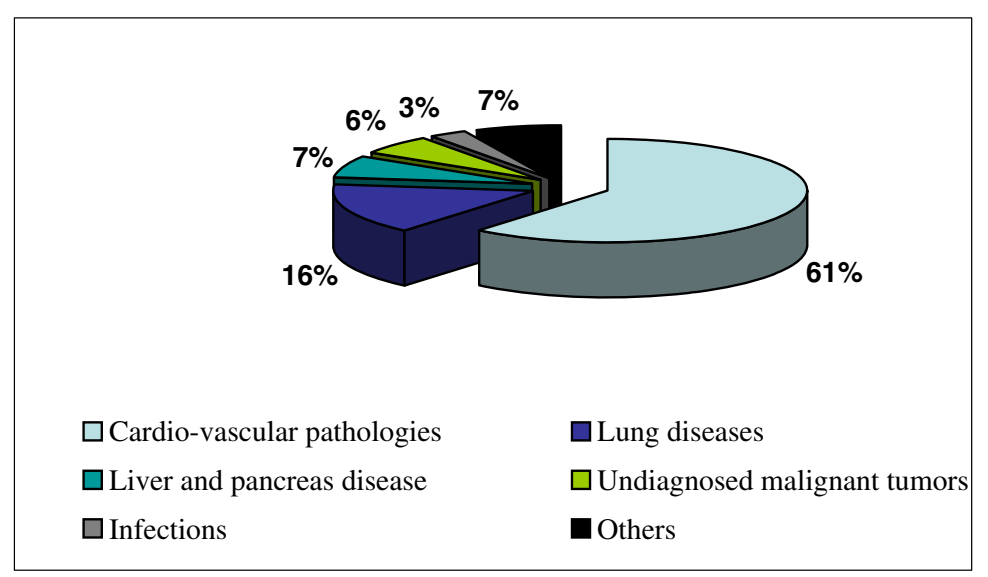

Figure 3. The main pathologies from which persons died out of hospitals.

People's Health, 2009). Medical documentation of dead persons shown that patients have not visited family doctor during last 3-5-10 years. Part of persons even have not done registration to any family doctor. A lot of patients had severe 2-4 concomitant pathologies.

\section{Discussion}

To decrease the amount of mortality cases at home without medical aid there must be active actions of family doctors. In Latvia we have some screening systems in oncology but not in general medicine e.g. in cardiology, pulmonology or gastroenterology. But in cases of neglected diseases patients themselves must be responsible for their own health too. Alarming are dates about the death of middle aged persons (Latvian health care Statistical Yearbook, 2008) which happen may be due to financial problems, unavailable doctors, long way to the specialists in the system of public health of Latvia. In Latvia there is lack of preventive measures and there is urgent necessity of costless medical offices for poor and defenceless persons how it was historically in Latvia. To our experience health insurance system in Latvia must be renewed and based on the proportion payroll from salary as it is now in a lot of European 


\section{SHS Web of Conferences}

countries (Henke, 2007). In England, Germany, etc. health care is realised through governmental (77\%), private $(23 \%)$, international health insurance systems and even health care free of charge. To decrease mortality at home without medical aid is possible with the involvement of medical staff in providing information about disease symptoms, diagnosis and treatment options in Riga and different Latvian districts with various media channels.

\section{Conclusions}

1. To decrease amount of mortality cases at home without medical aid there must be active actions of family doctors and screening system have to be introduced for nononcology diseases too. 2. Patient's delay in seeking medical help is the decisive phase for late diagnosis of curable diseases and mortality. 3. In Latvia there must be improved preventive measures of diseases and introduced best standards of health care policy of European countries irrespective of income of population.

\section{References}

[1] Anonīms (2008) Latvijas veselības aprūpes statistikas gadagrāmata. [Latvian health care Statistical Yearbook]. Latvijas valsts Veselības ministrija. Veselības statistikas un medicīnas tehnologíiju valsts aǵentūra.

[2] Anonīms (2009) Tautas veselības gadagrāmata. [Yearbook of the People's Health]. Sabiedrības veselības aǵentūra. Latvijas valsts Veselības ministrija.

[3] Anonīms (2009) Veselības statistikas rādītāji. Definīcijas, formulas un datu ieguves avoti. [Health statistics. Definitions, formulas and data sources]. Veselības statistikas un medicīnas tehnoloǵiju valsts ağentūra. Latvijas valsts Veselības ministrija. http://www.nhs.uk

[4] Arhipova, I., Bāliņa, S. (2000) Statistika ar Microsoft Excel ikvienam. [Statistics with Microsoft Excel for everyone]. 2. daļa. Rīga: Datorzinību Centrs.

[5] Gringlazs, L., Kopitovs, J. (2003) Matemātiskā statistika. [Mathematical Statistics]. Rīga: RSEBAA.

[6] Henke, K.D. (2007) Mittelaufbringung und Mittelverwendung im Gesundheitswesen. Medizinische klinik, 102 (5), S 366-372.

[7] Kleina, R. (2003) Rīgas iedzīvotāju mirstības medicīniskie aspekti (2002-2003). [Medical Aspects of Mortality between the Citizens of Riga in year 2002-2003]. RSU Medicīnas Zinātniskā konference, 2003.

[8] Anonīms (2009) Latvijas iedzīvotāju veselības un veselības aprūpes pārskats. [Latvian population health and health care review]. Veselības statistikas un medicīnas tehnolog̣iju valsts ağentūra. Latvijas valsts Veselības ministrija.

[9] Kleina, R. (2006) Koronārās sirds slimības formas - patologu pieredze. [Variations of Coronary Heart Disease - the Experiance of Pathologists]. RSU 2006. gada Zinātniskā konference, 2006.

[10] Raudseps, P. (2011) Biezie un plānie. [Thick and thin]. Ir, 50 (18), p. 14-1 